\title{
Publishing and Society: A Comparative Analysis of Bourdieu's Field Theory and Paradigm of External Analysis using the Case of the Book Publishing Industry in China
}

\author{
Ruoxing Cao \\ Department of Social \& Historical Sciences, University College London, London WC1E 6BT, \\ United Kingdom \\ Ucsarc2@ucl.ac.uk
}

\begin{abstract}
The publishing industry has a long history of development as an integral part of people's social life. This essay provides a preliminary exploration of the special status of the publishing industry in sociological research through a comparative analysis of Bourdieu's field theory and the Marxist-oriented external analysis paradigm. It critically assesses the Chinese publishing industry, with its strong political and complex historical background, by analyzing the external relations and field characteristics of the Chinese publishing industry. Due to the social peculiarities of China's socialist system coexisting with the market economy system, the state of political influence intersecting with social class influence is also taken into account in the analysis.
\end{abstract}

Keywords: Publishing Industry; Sociological Research; Bourdieu's Field Theory; Marxist-oriented External Analysis Paradigm; Political Influence.

\section{Introduction}

The publishing industry has a long history of development as an integral part of people's social life. There is no doubt that the publishing industry has provided a strong foundation for the development of human civilization and social progress. This essay provides a preliminary exploration of the special status of the publishing industry in sociological research through a comparative analysis of Bourdieu's field theory and the Marxist-oriented external analysis paradigm. The essay then critically assesses the Chinese publishing industry, with its strong political and complex historical background, by analyzing the external relations and field characteristics of the Chinese publishing industry. Due to the social peculiarities of China's socialist system coexisting with the market economy system, the state of political influence intersecting with social class influence is also taken into account in the analysis.

\section{Field Theory and External Analysis Model Study}

\subsection{Bourdieu's Theory}

Bourdieu's theory of the literary field has had an important influence on the publishing industry today, defining the literary work as a 'republic of letters' (Bourdieu 1993,179) and advocating that it be read from within. He, therefore, saw the publishing field as a 'relatively autonomous social space' (Bourdieu 2008,127), a space 'one capable of translating all external forces (economic and political) according to its own particular logic'. (Bourdieu 2008,127) Within this spatial field, Bourdieu analyzed sixteen external fields related to publishing, such as capital, language, the market, social class, and so on. Bourdieu pointed out that although these fields hide the autonomous space of the publishing industry behind a veil of secrecy, we can still feel the intrinsic connection between editing and books through the analysis of these factors. For literary creative activity, the first major function of publishing is to bring literary works into existence. Bourdieu categorized the size and function of publishing institutions, 'innovative publishers may not exercise much influence in the field, but they are nonetheless its raison d'être. They justify its existence, represent its ideals.' (Bourdieu 2008,135) Large publishing groups, on the other hand, 'concurrently retain all forms of economic, commercial and symbolic capital.' (Bourdieu 2008,136) The different standards of the publishing industry may 
therefore vary according to the capital and social class of the publisher. For Bourdieu, such distinctions accentuate the autonomy of the publishing field, as the distinctions represent a heterogeneity of standards that is difficult to regulate explicitly by external standards. The second function of publishing is to transform commercial acts into literary events. Bourdieu noted the dual nature of books 'A book's dual nature - as both a signifier and a commodity, a symbolic and an economic entity', (Bourdieu 2008,138) which required ' an editor to have a dual character, one that can reconcile art and money, love of literature and the pursuit of profit, by devising strategies situated somewhere between the two extremes of cynical subservience and heroic indifference to the house's economic needs. '(Bourdieu 2008,138) This act of transformation helped to ensure the independent identity of publishing editors in an autonomous publishing space, and they helped to bring about a gradual and profound change in the field of publishing.

\subsection{External Analysis Paradigm}

In contrast, the external analysis paradigm, guided by Marxism, advocates an external analysis of the literary and artistic spheres, which belong to the superstructure and are closely linked to the class struggle. Although the external research paradigm also sees literary and artistic works as playing an important orienting role in the social space, it does not recognize the 'independent literary space' that Bourdieu proposes, but sees these works as closely linked to social interests, a view that Bourdieu refers to as 'imputations of spiritual paternity'. (Bourdieu 1993,178) Furthermore, the external paradigm of analysis did not believe that published works could exist independently of social interests, as Marx noted that 'The mode of production of material life conditions the general process of social, political and intellectual life. It is not the consciousness of men that determines their existence, but their social existence that determines their consciousness.' (Marx 1859) Here, transformation and change in the publishing sphere is dominated by changes in productivity, and material existence has absolute dominion over the publishing sphere. For it is only when people feel the contradictions from their material life that they can initiate the struggle and challenge the ideological sphere, such as literature and art. According to Bourdieu, this approach to the analysis of literary works purely from the outside is naive in the extreme. In fact, external analysis should exist as part of the study of publication, and it is only by placing the author in the external relations of the time, by combining external determinants with internal links, that we can better understand literary works. For 'The enjoyment of a work has as its condition the consciousness and knowledge of the space of possibilities of which the work is the product, of the "contribution" which the work represents, and which cannot be grasped except by historical comparison. '(Bourdieu 1993,186) By comparing field theory with external analytical paradigms, it can be concluded that it is difficult to fully grasp the characteristic structure of the intertwined social, economic and literary aspects of the publishing industry using only external research methods.

\section{Case Studies \& Results Analysis}

In the theoretical analysis described above, external methods of analysis do not seem to be at the forefront of the study of publishing and society. However, two main examples present the particularities of the publishing industry in China: the institutional norms of publishing houses and the tendency of local authors to be marginalized.

\subsection{Marginalized Authors: Flow Rates, Markets, and Social Hotspots}

According to Bourdieu's field theory, authors act as the core of an independent literary space, their works create history and give birth to classics. However, this author-centered model of literary creation in China has developed in an aberrant way. Firstly, due to China's market economy orientation and highly centralized political system of publishing, the power to publish books is concentrated in the hands of a few publishing houses. In order to maximize economic efficiency, publishing editors prefer to adapt to the flow rates effect and select authors with a fan base for book 
publishing, with the consequence that many local Chinese writers cannot find publishing opportunities and the book market is flooded with homogenized books. As a result, the publishing editor, who is supposed to be balancing the roles of money and art in the literary field of publishing, has deviated, leaving a large number of authors out of the publishing space. On the other hand, Chinese literary activity is often characterized by a combination of cultural inferiority and cultural complacency. Due to China's complex historical background, 'Modern Chinese have combined an admiration for Western modernity with a resentful inferiority complex towards Western strength and a fear that the Chinese national essence will be lost in the process of modernization.' (Lovell 2006,7) This mentality has led the Chinese book publishing market to display a blind admiration for imported translated texts and blind confidence in traditional literary works, especially children's books. The author has worked for a children's book publishing company, and extensive market research has shown that Chinese parents prefer children's books written by foreign authors to traditional Chinese literary picture books for their children. What is of urgent concern is that this market choice squeezes the creative space of authors. According to Bourdieu, this results in Chinese literature not being able to purify its creation and restore its historical process, and its literary artistry is relatively weakened.

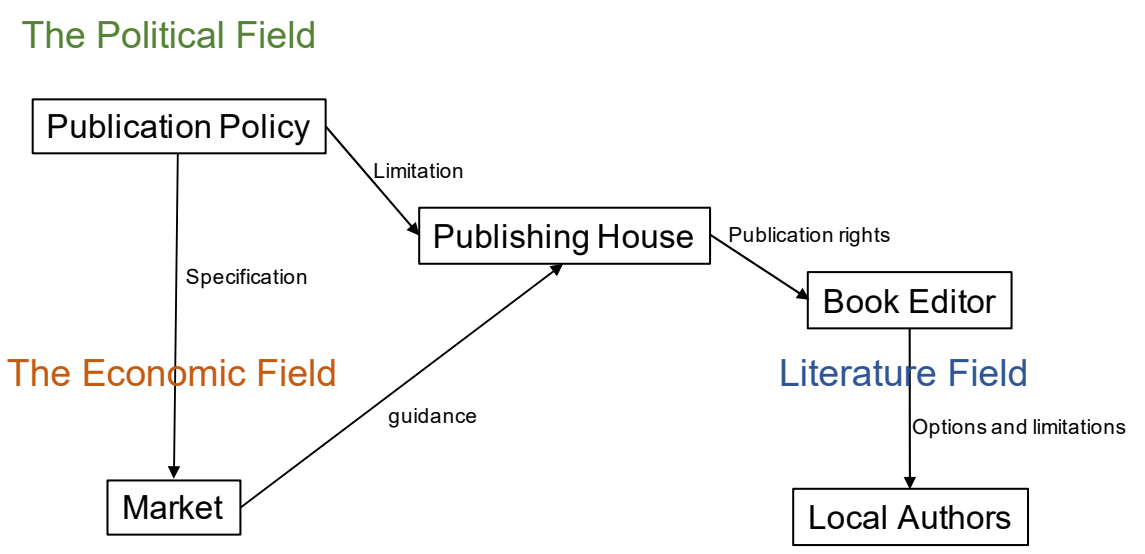

Figure 1. The Relationship between the Political System, Market, Publishers and Local Authors

\subsection{The Regulation of Publishing Houses: the Intertwining of Historical Background and Social System}

Due to the norms of China's socialist system, the publishing industry in China has long been under government regulation. But, 'to a certain extent, the introduction of market mechanisms into a planned economy requires relaxation of the control exerted by the Chinese state. (...) This opening of space has led to tensions between media practitioners and propaganda officials.' (Stockmann 2013) As a result, the publishing industry, as a state institution and a commercial system, has a firm grip on the choice of book titles and the power to publish them. In the case of China's National Publication Fund, for example, each year, the Chinese government uses state funds to select and fund outstanding publishing projects that are required to meet the publication criteria outlined by the government. In the case of the 2020 selection criteria, for example, publications need to meet the following themes: "excellent projects that deeply promote and explain the Party's innovative theories and promote the core values of socialism; publishing projects that show the development and changes in contemporary China and promote the spirit of poverty eradication and the fight against epidemics; theoretical works that focus on major issues and key problems of national economic and social development, as well as practical summaries and theoretical works that focus on the major issues and key problems of national economic and social development and conduct practical summaries and theoretical explorations; a number of academic masterpieces that reflect the latest research results in the fields of natural science and engineering technology and represent China's major achievements in scientific and technological innovation; outstanding projects that promote the creative transformation and innovative 
development of outstanding Chinese traditional culture, etc. These criteria highlight the external policy-oriented nature of the Chinese publishing market. The author's children's picture book also participated in the 2020 China National Publication Fund application, during which the author revised the creative content several times in accordance with the review and policy requirements. This experience led to a strong connection between the author's finished picture book and the external environment. This tends towards the values of the external research paradigm, where material existence has absolute dominion over the publishing field and published works cannot exist independently of social interests.

\section{Discussions and Reflections}

In the long process of Chinese writers' attempts to forge a modern Chinese literary and cultural identity, the internationalization of Chinese literary works has mainly focused on the export of cultural landscapes and cultural experiences, which have been too superficial. As a result, Chinese writers have long been confronted with the problem of 'Cheesiness' in their literary creations, neglecting the 'pure' literary quality of their works. Moreover, the external analysis paradigm has a unique role in the Chinese publishing market, especially in historical studies, which are closely linked to the changes of the times. 'True enough, the weaknesses in modern Chinese literature are sufficiently obvious since the start of the twentieth century have interrupted the maturation process of a modern literature; the intrusion of politics into the literary realm, particularly after 1949, has stifled literary creativity as Chinese writers, critics, and editors have not been able to withstand these incursions; in the 1990s, as overt politicization of literature has decreased, "serious" writers have been unable to resist new commercial temptations and have consequently neglected literary quality.' (Lovell 2006,30) China's publishing market has long been marginal to the world literary market, due to its overpowering political context and history, and readers tend to read them for external factors, for example out of curiosity about politics, rather than on the basis of the literary qualities of the works themselves. With the development of China's international outlook, can the Chinese publishing industry break out of the cycle of exporting cultural landscapes and cultural experiences, and try to create cultural narratives? Does this mean that Chinese publications can truly confront history and society in its entirety, and reach a broader and more appreciative audience? Finally, can the Chinese publishing industry find a balance between the literary field and the external environment through the development of cultural narratives?

\section{Summary}

It is worth discussing that both Bourdieu's field theory and the Marxist-influenced model of external analysis have had a significant impact on the publishing industry in China. The publishing industry in China has gradually developed under the dual regulation of internal creativity and external norms. Today, however, in the context of the COVID-19 global pandemic, Chinese author Fang Fang's overseas publication "Wuhan Diary" has generated a great deal of discussion in China for its overly derogatory worsening of the situation in Wuhan, China, during the city's closure by the epidemic. It cannot be denied that there are still a large number of local writers in China who have a politically driven tendency in their literary work, a simple literary dissent of 'such- and-such a work is propaganda for the Chinese government (or Communist Party); the Chinese government (or Communist Party) is bad/good; therefore this work is bad/good' (Lovell 2006,32) Thankfully, however, Chinese youth are gradually breaking out of their cultural inferiority complex, refuting, and countering such literature on social media platforms, and taking practical action to support the creation of good cultural narratives. This change has the potential to help Chinese writers reconstruct the publishing field by deconstructing the field. 


\section{References}

[1] Stockmann, D. 2013. Media Commercialization and Authoritarian Rule in China. Cambridge University Press. Retrieved 06 January 2021, from https: //Doi-org. libproxy. ucl. ac. uk/ 10. 1017/ CBO9 78113908 7742.008.

[2] Bourdieu, P. 1993. Principles for a Sociology of Cultural Works. Cambridge University Press. Retrieved 06 January 2021, from https://www.cambridge.org/core.

[3] Bourdieu, P. 2008. "A conservative revolution in publishing." Journal Of Translation Studies, Volume 1, Issue 2: 123-153. Retrieved 06 January 2021, from https://www.tandfonline.com/loi/rtrs20.

[4] Marx, K. 1859. A Contribution to the Critique of Political Economy. Progress Publishers, Moscow. Retrieved 06 January 2021, from https://www.marxists.org/archive/marx/works/1859/critique-poleconomy/ preface. htm.

[5] Lovell, J. 2006. The politics of cultural capital: China's quest for a Nobel Prize in literature. University of Hawaii Press. Retrieved 06 January 2021, from muse.jhu.edu/book/8193.

[6] People's Daily. 2020. National Publication Fund Announces "Report Card" - Over 5,700 outstanding publication projects selected for funding. Last modified December 23, 2020. http:// www. npf.org. cn/detail. html? id=2016\&categoryId=26.

[7] Pinyue, L. 2020. "Fang Fang's Diary: An Indefensible Mistake.” Journal Of International Critical Thought, Volume 10, Issue 3:483-493. Retrieved 06 January 2021, from https:// Doi. org/ 10.1080/ 21598282.2 020.1823612 . 